\title{
CHD5 Gene
}

National Cancer Institute

\section{Source}

National Cancer Institute. CHD5 Gene. NCI Thesaurus. Code C68557.

This gene is involved in both chromatin structure regulation and tumor suppression. 